\title{
Variations of the Moles Percent Guanine plus Cytosine Within a Group of Enterobacteriaceae Belonging or Related to the Genus Enterobacter
}

\author{
D. IZARD, C. FERRAGUT, F. GAVINI, AND H. LECLERC \\ Institut Pasteur de Lille, Unité INSERM 146, Domaine du C.E.R.T.I.A., B.P. 15, \\ 59650 Villeneuve d'Ascq, France
}

\begin{abstract}
This study is a measurement of the moles percent guanine plus cytosine of 34 strains of bacteria belonging or related to the genus Enterobacter. All of the strains included in the sampling have been previously studied by numerical taxonomy, which has shown four new classes: $\mathrm{H}_{1}, \mathrm{H}_{2}, \mathrm{H}_{3}$, and $\mathrm{d}$. The average guanine-plus-cytosine contents for the defined species and of the new classes are: Enterobacter cloacae (10 strains), 54.5 mol\% (standard deviation, 1.32); Hafnia alvei (5 strains), $48.1 \mathrm{~mol} \%$ (standard deviation, 1.0); Enterobacter agglomerans (syn. Erwinia herbicola) (1 strain), $52.4 \mathrm{~mol} \%$ (standard deviation, 0.41); Serratia liquefaciens (1 strain), 50.9 mol\% (standard deviation, 1.22); Enterobacter aerogenes (1 strain), $53.5 \mathrm{~mol} \%$ (standard deviation, 0.29); class $\mathrm{H}_{1}$ (5 strains), $52.2 \mathrm{~mol} \%$ (standard deviation, 1.3); class $\mathrm{H}_{2}$ (5 strains), $53.4 \mathrm{~mol} \%$ (standard deviation, 1.9); class $\mathrm{H}_{3}$ (5 strains), $54.2 \mathrm{~mol} \%$ (standard deviation, 0.1 ); class d (1 strain), $52.6 \mathrm{~mol} \%$ (standard deviation, 1.45). The importance of the guanine-pluscytosine contents for discriminating defined species and new classes is discussed.
\end{abstract}

The purpose of this study is to define the guanine-plus-cytosine contents $(\mathrm{G}+\mathrm{C})$ for the Enterobacteriaceae belonging or related to the genus Enterobacter. It is a continuation of the numerical taxonomy work of Gavini et al. (9) on 175 strains, which regrouped defined species such as Enterobacter cloacae (class G), Hafnia alvei (class I), Enterobacter agglomerans, syn. Erwinia herbicola (class a), Serratia liquefaciens (class b), Enterobacter aerogenes (class c), and new classes $\left(\mathrm{H}_{1}, \mathrm{H}_{2}, \mathrm{H}_{3}\right.$, and $\left.\mathrm{d}\right)$.

\section{MATERLALS AND METHODS}

The 34 strains used are listed in Table 1; all were included in the study of Gavini et al. (9). The preparation of the deoxyribonucleic acid and the determination of the melting temperature $\left(T_{m}\right)$ were described by Ferragut and Leclerc (8). The absorbance measurements at $260 \mathrm{~nm}$ have been corrected for the concentration dilution caused by solvent expansion at the higher temperature (15). The $\mathrm{mol} \% \mathrm{G}+\mathrm{C}$ has been measured by the average $T_{m}$ as described by De Ley (6).

\section{RESULTS}

The results of the $\mathrm{G}+\mathrm{C}$ determinations are shown in Tables 2 (defined species) and 3 (undefined species). Table 4 compares our results with those cited in the literature. The precision of the determinations is $\pm 1.1 \%$ at a $95 \%$ level of confidence. The standard deviation shows the homogeneity of the taxons.
Defined species. (i) E. cloacae. The average $\mathrm{G}+\mathrm{C}$ content for $E$. cloacae $(54.5 \mathrm{~mol} \%)$ was measured from 10 strains and was the highest of all the analyzed species and classes. The range of results (standard deviation, 1.32) showed a certain heterogeneity previously revealed by numerical analysis. Very few determinations of $E$. cloacae $\mathrm{G}+\mathrm{C}$ content are cited in literature. Ouelette et al. (19) determined the $\mathrm{G}+\mathrm{C}$ content of $E$. cloacae CDC $1237-63$ to be $56.9 \mathrm{~mol} \%$ by the $T_{m}$ method. This value is close to the upper limit of our results ( 52.6 to $56.4 \mathrm{~mol} \%$ ). The $\mathrm{G}+\mathrm{C}$ content of $E$. cloacae ATCC 13047 was found by Starr and Mandel (22) to be $54.6 \mathrm{~mol} \%$ by the buoyant density method and $55.4 \mathrm{~mol} \%$ by the $T_{m}$ method.

(ii) $H$. alvei. The average $\mathrm{G}+\mathrm{C}$ content of this species was $48.1 \mathrm{~mol} \%$ (five determinations), which is different from those of the other groups ( $E$. cloacae, $\mathrm{H}_{1}, \mathrm{H}_{2}$, and $\mathrm{H}_{3}$ ). The standard deviation (1.0) showed a good homogeneity in the results. The study of this group agrees with the conclusions of the numerical analysis. Our results confirmed the maintenance of the level of genus for the bacteria belonging to the Hafnia group $(2,12,22,23)$. Our measurements agree with those of Starr and Mandel (22), who cite 48 mol\% $\left(T_{m}\right)$ and $48.7 \mathrm{~mol} \%$ (buoyant density) for H. alvei ATCC 23280. They are, on the other hand, very different from the range of 52 to 57 mol\% given by Sakazaki (20) in the 8th edition of Bergey's Manual. 
(iii) E. agglomerans syn. E. herbicola. The average $\mathrm{G}+\mathrm{C}$ content of strain 18 was 52.4 mol\%, which is close to the lower part of the range of 52.6 to $57.7 \mathrm{~mol} \%$ derived from the 30 strains cited by Lelliot (14) in the 8th edition of Bergey's Manual.

(iv) S. liquefaciens. The strain analyzed was S. liquefaciens ATCC 14460 . The $\mathrm{G}+\mathrm{C}$ content was $50.9 \mathrm{~mol} \%$, which is close to the Mandel and Rownd (16) finding of $51.9 \mathrm{~mol} \%\left(T_{m}\right)$ for the same strain. On the other hand, our determina- tion disagrees with the values of $53.9 \mathrm{~mol} \%$ by the $T_{m}$ method and $52.6 \mathrm{~mol} \%$ by the buoyant density method cited by Starr and Mandel (22) in a paper published more recently. The $\mathrm{G}+\mathrm{C}$ content of this strain was also determined by the chemical method: Marmur et al. (18) found 50 to $52 \mathrm{~mol} \%$.

(v) E. aerogenes. The $\mathrm{G}+\mathrm{C}$ content of the strain analyzed, $E$. aerogenes ATCC 13048 , was $53.5 \mathrm{~mol} \%$. This value is close to those cited in literature by several authors who mention, for

TABLE 1. List of strains of bacteria used ${ }^{a}$

\begin{tabular}{|c|c|}
\hline Species (class) & Strain no. \\
\hline Enterobacter cloacae (class G) & $13,35,42,45,53,87,97,127,132,137$ \\
\hline Hafnia alvei (class I) .......... & H. alvei ATCC $13337,71,94,114,120$ \\
\hline Enterobacter agglomerans (class a) & 18 \\
\hline Serratia liquefaciens (class b) ..... & S. liquefaciens ATCC 14460 \\
\hline Enterobacter aerogenes (class c) & E. aerogenes ATCC 13048 \\
\hline Class $\mathrm{H}_{1}$ (undefined strains) $\ldots$. & $66,86,99,134,146$ \\
\hline Class $\mathrm{H}_{2}$ (undefined strains) & $80,91,133,148,171$ \\
\hline Class $\mathrm{H}_{3}$ (undefined strains) & $111,123,130,145,175$ \\
\hline Class $\mathrm{d}$ (undefined strains) & 160 \\
\hline
\end{tabular}

${ }^{a}$ All are included in the numerical analysis of Gavini et al. (9).

TABLE 2. $G+C$ content of defined species

\begin{tabular}{|c|c|c|}
\hline Species and strain no. & $\begin{array}{l}\text { No. of } \\
\text { determi- } \\
\text { nations }\end{array}$ & $\begin{array}{c}\text { Mean } G+C \\
\text { content for } \\
\text { the determi- } \\
\text { nations }{ }^{a} \\
(\text { mol \%) }\end{array}$ \\
\hline \multicolumn{3}{|l|}{ Enterobacter cloacae } \\
\hline 97 & 6 & 52.6 \\
\hline 42 & 5 & 52.7 \\
\hline 87 & 4 & 53.6 \\
\hline 127 & 5 & 53.7 \\
\hline 13 & 3 & 54.5 \\
\hline 35 & 7 & 54.9 \\
\hline 137 & 3 & 55.4 \\
\hline 45 & 4 & 55.7 \\
\hline 132 & 3 & 55.7 \\
\hline 53 & 3 & 56.4 \\
\hline \multicolumn{3}{|l|}{ Hafnia alvei } \\
\hline 120 & 5 & 47.2 \\
\hline 94 & 3 & 47.4 \\
\hline ATCC 13337 & 5 & 47.7 \\
\hline 71 & 3 & 48.8 \\
\hline 114 & 5 & 49.5 \\
\hline $\begin{array}{l}\text { Enterobacter agglomerans } \\
18\end{array}$ & 3 & 52.4 \\
\hline $\begin{array}{l}\text { Serratia liquefaciens } \\
\quad \text { ATCC } 14460\end{array}$ & 5 & 50.9 \\
\hline E. aerogenes ATCC 13048 & 3 & 53.5 \\
\hline
\end{tabular}

TABLE 3. $G+C$ content of undefined classes of Enterobacteriaceae

\begin{tabular}{ccc}
\hline $\begin{array}{c}\text { Class and } \\
\text { strain no. }\end{array}$ & $\begin{array}{c}\text { No. of deter- } \\
\text { minations }\end{array}$ & $\begin{array}{c}\text { Mean G + C con- } \\
\text { tent for the deter- } \\
\text { minations } \\
\text { (mol\%) }\end{array}$ \\
\hline Class H H $_{1}$ & & \\
86 & 3 & 50.3 \\
146 & 3 & 51.4 \\
66 & 5 & 52.6 \\
99 & 4 & 53.0 \\
134 & 3 & 53.6 \\
& & \\
Class $\mathrm{H}_{2}$ & & \\
133 & 4 & 51.3 \\
148 & 4 & 52.0 \\
80 & 4 & 53.0 \\
91 & 3 & 54.7 \\
171 & 3 & 55.9 \\
& & \\
Class H & & \\
175 & 4 & 53.2 \\
111 & 4 & 53.8 \\
123 & 3 & 53.9 \\
145 & 3 & 54.3 \\
130 & 3 & 55.8 \\
& & \\
Class d & 5 & 52.6 \\
160 & 5 & \\
\hline
\end{tabular}

${ }^{a}$ The average $\mathrm{G}+\mathrm{C}$ content (moles percent) \pm standard deviation values for the classes $\mathrm{H}_{1}, \mathrm{H}_{2}$, and $\mathrm{H}_{3}$ were $52.2 \pm 1.3,53.4 \pm 1.9$, and $54.2 \pm 0.1$, respectively. 
TABLE 4. Comparison of our results with those in the literature

\begin{tabular}{|c|c|c|c|c|c|c|}
\hline \multirow{3}{*}{ Species } & \multirow{3}{*}{$\begin{array}{l}\text { G + C content: } \\
\text { Izard et al. } \\
\quad \text { (mol\%) }\end{array}$} & \multicolumn{5}{|c|}{ Data from other sources } \\
\hline & & \multirow[b]{2}{*}{ Strain } & \multicolumn{3}{|c|}{$\mathrm{mol} \% \mathrm{G}+\mathrm{C}$ by: } & \multirow[b]{2}{*}{$\begin{array}{l}\text { Refer- } \\
\text { ence }\end{array}$} \\
\hline & & & $\begin{array}{c}T_{m} \\
\text { method }\end{array}$ & $\begin{array}{l}\text { Buoyant } \\
\text { density } \\
\text { method }\end{array}$ & $\begin{array}{l}\text { Chemical } \\
\text { method }\end{array}$ & \\
\hline $\begin{array}{l}\text { Enterobacter } \\
\text { cloacae }\end{array}$ & $\begin{array}{l}52.6-56.4 \\
10 \text { strains }\end{array}$ & $\begin{array}{l}\text { ATCC } 13047 \\
\text { CDC } 1237-63\end{array}$ & $\begin{array}{l}55.4 \\
56.9\end{array}$ & 54.6 & & $\begin{array}{l}22 \\
19\end{array}$ \\
\hline \multirow[t]{2}{*}{ Hafnia alvei } & $\begin{array}{l}47.2-49.5 \\
5 \text { strains }\end{array}$ & ATCC 23280 & 48.7 & 48.0 & & 22 \\
\hline & & & & $52-57$ & & 20 \\
\hline $\begin{array}{l}\text { Enterobacter } \\
\text { agglomerans }\end{array}$ & $\begin{array}{l}52.4, \\
\quad 1 \text { strain }\end{array}$ & 30 strains & & $52.6-57.7$ & & 14 \\
\hline $\begin{array}{l}\text { Serratia lique- } \\
\text { faciens }\end{array}$ & $\begin{array}{l}50.9 \\
\text { ATCC } 14460\end{array}$ & $\begin{array}{l}1 \text { strain } \\
\text { ATCC } 14460 \\
\text { ATCC } 14460 \\
\text { ATCC } 14460\end{array}$ & $\begin{array}{l}53.8 \\
53.9 \\
51.9\end{array}$ & 52.6 & $50-52$ & $\begin{array}{l}11 \\
22 \\
16 \\
18\end{array}$ \\
\hline $\begin{array}{c}\text { Enterobacter } \\
\text { aerogenes }\end{array}$ & $\begin{array}{l}53.5, \\
\quad \quad \text { ATCC } 13048\end{array}$ & $\begin{array}{l}\text { ATCC } 13048 \\
\text { ATCC } 13048 \\
\text { ATCC } 13048 \\
5 \text { strains } \\
5 \text { strains } \\
1088 \text { (Harvard) } \\
1088 \text { (Harvard) } \\
2 \text { strains } \\
3 \text { strains } \\
9 \text { strains }\end{array}$ & $\begin{array}{c}54.9 \\
\\
54.0-56.5 \\
57.5 \\
\\
57.8 \\
56.4-60.8\end{array}$ & $\begin{array}{c}53.1 \\
53.1 \\
54.3 \\
54.0-56.5 \\
\\
\\
57.0\end{array}$ & $55.2-58.9$ & $\begin{array}{r}22 \\
1 \\
4 \\
4 \\
3 \\
17 \\
21 \\
19 \\
7 \\
19 \\
19\end{array}$ \\
\hline
\end{tabular}

the same strain, $54.9 \mathrm{~mol} \%$ by the $T_{m}$ method (22) and 53.1 to $54.3 \mathrm{~mol} \%$ by the buoyant density method $(1,4,22)$. Many authors have measured the base composition of $E$. aerogenes which is near that of E. cloacae: Ouelette et al. (19) (nine strains), 56.4 to $60.8 \mathrm{~mol} \%$; Colwell and Mandel (4) (five strains), 54.0 to 56.5 mol\%; Falkow et al. (7) (three strains), 57.8 mol\%; Belozerskii and Spirin (3) (five strains), 55.2 to $58.9 \mathrm{~mol} \%$; Marmur and Doty (17) and Schildkraut et al. (21) (the same strain [Harvard 1088]), 57.5 and $57.0 \mathrm{~mol} \%$, respectively. Like the $\mathrm{G}+\mathrm{C}$ content of $E$. cloacae, that of $E$. aerogenes varies within a wide interval (53.1 to 60.8 mol\%).

Undefined classes. The average $\mathrm{G}+\mathrm{C}$ content of class $\mathrm{H}_{1}$ was $52.2 \mathrm{~mol} \%$ (five determinations); the standard deviation was 1.3. The average $\mathrm{G}+\mathrm{C}$ content of class $\mathrm{H}_{2}(53.4 \mathrm{~mol} \%)$ was close to that of $E$. cloacae; this tends to confirm the conclusions of the numerical analysis. As for the species $E$. cloacae, the standard deviation was relatively high (1.9). The average $\mathrm{G}+\mathrm{C}$ content of class $\mathrm{H}_{3}(54.2 \mathrm{~mol} \%)$ was approximately equal to that of $E$. cloacae. $\mathrm{H}_{3}$ is very homogeneous (standard deviation, 0.1 ) and phenetically close to the species E. cloacae. Class d consisted of three strains; the $\mathrm{G}+\mathrm{C}$ content of strain 160 was $52.6 \mathrm{~mol} \%$. According to a previous numerical taxonomic study, these strains should belong to the group "Citrobacter lysine ${ }^{+"}$ (Leclerc and Buttiaux [13]), syn. "Citrobacter like" (Crosa et al. [5]), class C (Gavini et al. [10]).

\section{DISCUSSION}

The results obtained agree with the conclusions of numerical analysis ( $E$. cloacae, $H$. alvei, $\mathrm{H}_{1}, \mathrm{H}_{2}$, and $\mathrm{H}_{3}$ ), but the discriminatory value of $\mathrm{G}+\mathrm{C}$ content in the taxonomy of coliforms is low. It seems absolutely necessary to reproduce the measurements on a great number of strains of each species or class. The heterogeneity of $\mathrm{G}+\mathrm{C}$ content within a species or a class seems to give an account of the different base compositions mentioned for a same species by the different authors. In fact, one must remember the continuum made by $E$. cloacae and classes $\mathrm{H}_{1}, \mathrm{H}_{2}$, and $\mathrm{H}_{3}(54.5,52.2,53.4$, and $54.2 \mathrm{~mol} \%$, respectively) and the well individualized position of the bacteria belonging to the group Hafnia (48.1 mol\%). 


\section{ACKNOWLEDGMENTS}

We thank Profeseor J. De Ley for his advice and for permission for one of us to work for some time in his laboratory, and we thank A. Bernigaud for his technical assistance.

\section{REPRINT REQUESTS}

Address reprint requests to: Daniel Izard, Institut Pasteur de Lille, Unité INSERM 146, Domaine du C.E.R.T.I.A., B.P. 15, 59650 Villeneuve d'Ascq, France.

\section{LTHRATURE CITED}

1. Baptiot, J. N., C. R. Shaw, and M. Mandel 1969. Zone electrophoresis of enzymes in bacterial taxonomy. $J$. Bacteriol. 98:180-188.

2. Bascomb, S., S. P. Lapage, M. A. Curtis, and W. R. Willcox. 1974. Identification of bacteria by computer: identification of reference strains. J. Gen. Microbiol. 83:271-282.

3. Belozerskii, A. N., and A. B. Spirin. 1960. p. 147. In E. Chargaff and J. N. Davison (ed.), The nucleic acids: chemistry and biology, vol. 3. Academic Press Inc., New York.

4. Colwell, R. R., and M. Mandel. 1964. Adansonian analysis and deoxyribonucleic acid base composition of some gram-negative bacteria. J. Bacteriol. 87: 1412-1422.

5. Crosa, J. H., A. G. Steigerwalt, G. R. Fanning, and D. J. Brenner. 1974. Polymucleotide sequence divergence in the genus Citrobacter. J. Gen. Microbiol. 83:271-282.

6. De Ley, J. 1970. Reexamination of the association between melting point, buoyant density, and chemical base composition of deoxyribonucleic acid. J. Bacteriol. 101:738-754.

7. Falkow, S., I. R. Ryman, and O. Washington. 1962. Deoxyribonucleic acid base composition of Proteus and Providence organisms. J. Bacteriol. 83:1318-1321.

8. Ferragut, C., and H. Leclerc. 1976. Etude comparative des méthodes de détermination du T $m$ de l'ADN bactérien. Ann. Microbiol. (Inst. Pasteur) 127A:223-235.

9. Gavini, F., C. Ferragut, B. Lefebvre, and H. Leclerc. 1976. Etude taxonomique d'entérobactéries appartenant ou apparentées au genre Enterobacter. Ann. Microbiol. (Inst. Pasteur) 127B:317-335.

10. Gavini, F., B. Lefebvre, and H. Leclerc. 1976. Positions taxonomiques d'entérobactéries H2S' par rapport au genre Citrobacter. Ann. Microbiol. (Inst. Pasteur) 127A:275-295.

11. Grimont, P. A. D., F. Grimont, H. L. C. Dulong de Rosnay, and P. H. A. Sneath. 1977. Taxonomy of the genus Serratia. J. Gen. Microbiol. 98:39-66.

12. Johnson, R., R. R. Colwell, R. Sakazaki, and $\mathbf{K}$. Tamura. 1975. Numerical taxonomy study of the Enterobacteriaceae. Int. J. Syst. Bacteriol. 25:12-37.

13. Leclerc, H., and R. Buttiaux. 1965. Les Citrobacter. Ann. Inst. Pasteur (Lille) 16:67-74.

14. Lelliot, R. A. 1974. Genus XII: Erwinia, p. 332-339. In R. E. Buchanan and N. E. Gibbons (ed.), Bergey's manual of determinative bacteriology, 8th ed. The Williams and Wilkins Co., Baltimore.

15. Mandel, M., and J. Marmur. 1968. Use of ultraviolet absorbance temperature profile for determining the guanine plus cytosine content of DNA. Methods Enzymol. 12B:195-206.

16. Mandel, M., and R. Rownd. 1964. Deoxyribonucleic acid base composition in the Enterobacteriaceae: an evolutionary sequence, p. 585-597. In C. A. Leone (ed.), Taxonomic biochemistry and serology. Ronald Press, New York.

17. Marmur, J., and P. Doty. 1962. Determination of the base composition of deoxyribonucleic acid from its thermal denaturation temperature. J. Mol. Biol. 5:109-118.

18. Marmur, J., S. Falkow, and M. Mandel. 1963. New approaches to bacterial taxonomy. Annu. Rev. Microbiol. 17:329-372.

19. Ouelette, C. A., R. H. Burris, and P. W. Wilson. 1969 Deoxyribonucleic acid base composition of species of Klebsiella, Azotobacter and Bacillus. Antonie van Leeuwenhoek J. Microbiol. Serol. 35:275-286.

20. Salrazaki, R. 1974. Genus VIII: Hafnia, p. 325-326. In R. E. Buchanan and N. E. Gibbons (ed.), Bergey's manual of determinative bacteriology, 8th ed. The Williams and Wilkins Co., Baltimore.

21. Schildkraut, C. L., J. Marmur, and P. Doty. 1962 Determination of the base composition of deoxyribonucleic acid from its buoyant density in $\mathrm{CsCl}$. J. Mol. Biol. 4:430-443.

22. Starr, M. P., and M. Mandel. 1969. DNA base composition and taxonomy of phytopathogenic and other enterobacteria. J. Gen. Microbiol. 56:113-123.

23. Veron, M., and L. Le Minor. 1975. Nutrition et taxonomie des Enterobacteriaceae et bactéries voisines. III. Caractères nutritionnels et différenciation des groupes taxonomiques. Ann. Microbiol. (Inst. Pasteur) 126B:125-147. 